\title{
The Effect of Regional Characteristics, Leverage, Government Complexity, BPK Audit Findings and Opinions on Local Government Financial Performance
}

\author{
Yulia Wijayanti*1 and Dhini Suryandari ${ }^{2}$ \\ ${ }^{1,2}$ Accounting Department, Faculty of Economics, Universitas Negeri Semarang
}

\section{ARTICLE INFO}

\section{Article History:}

Received March 23 $3^{\text {th }}, 2018$

Accepted March $3^{\text {th }}, 2020$

Available March $30^{\text {th }}, 2020$

\section{Keywords:}

Audit Findings and Opinion of BPK;

Complexity of Government;

Financial Performance;

Leverage;

Regional Characteristic

\begin{abstract}
The purpose of this research is to analyze the effect of variables of regional size, regional expenditure, regional wealth level, leverage, government complexity, audit findings and opinion of BPK on the financial performance of local government. The population of this research were 129 District / City in Java and Bali TA. 2014-2015. This research used purposive sampling with 202 samples of the reports of BPK-RI audit results in 2014-2015 and IHPS in 2015-2016. The analytical tool used in this research was multiple linear regression. The result of this research for variables of regional expenditure and audit opinion have a positive effect, while regional size has a negative effect, the level of regional wealth, leverage, government complexity and audit findings do not affect on the financial performance of the local government. The conclusion of this research is simultaneous testing shows the effect between independent and dependent variables. Size, regional expenditure and audit opinion have significant effect on the financial performance of the local government and the level of regional wealth, leverage, government complexity and audit findings do not have significant affect on the financial performance of the local government.
\end{abstract}

(C) 2020 Published by UNNES. This is an open access article under the CC BY license (http://creativecommons.org/licenses/by/4.0/)

\section{INTRODUCTION}

The policy on regional autonomy in Indonesia begins with the People's Consultative Assembly (MPR) Decree namely TAP MPR Number XV / MPR / 1998 which is subsequently affirmed in Law No. 22 of 1999 concerning Regional Government which until now has undergone several changes and the last is Law No. 9 of 2015 concerning Local Government. Based on this law, it is emphasized that with the existence of regional autonomy, the authority to organize Local Government is wider, real, and responsible. Citizens who are increasingly intelligent and critical always demand public transparency and accountability. Accountability is not just the ability to show how public money has been spent, but also includes the ability to show that public money has been spent economically, efficiently, and effectively (Kurrohman, 2013).

With the start of regional autonomy, assessment and evaluation are very important to ensure good governance. Thus, in the assessment and evaluation, measurement is certainly needed which will give an over-

\footnotetext{
*E-mail:wijayanti.yulia@outlook.com

_Address: L2 Building 2nd floor, Campus Sekaran, Gunungpati, Semarang, Indonesia, 50229
}

view of the extent to which the development of local government management independently after regional autonomy. Financial performance can be defined as the achievements achieved by the organization in a certain period. The demand for performance accountability by the community requires Local Government to provide a clear description of their performance. Performance measurement is an important component because it will provide feedback on plans that have been implemented (Chow et al., 1998). According to Wood (1998) the function of performance measurement explains about (1) Evaluation of how the program runs, (2) Means of comparison on services provided and (3) Tools of communication with the public.

The phenomena gap of this research is the increase in WTP opinion acquisition for district / city local government during the 2011-2015 period which experienced a significant increase of $45 \%$. As well as being interpreted as an increase in the Local Government's financial performance, seen from the aspect of financial reporting audited by BPK as the government's external auditor. However, State Apparatus Empowerment and Bureaucratic Reform (PAN-RB) Minister Asman Abnur stated that there are 435 local governments or $83 \%$ of districts / cities were still included in category 
C in AKIP (Government performance report card) with score only 30-50 points, which meant it was categorized as less.

Research gaps also occur in the results of the previous studies, such as research conducted by Noviyanti \& Kiswanto (2016) finds that variables of size, regional wealth level and audit findings do not affect on performance. Meanwhile, regional expenditure variable has a significant positive effect on performance. The results of the study for the variables of size, wealth level and regional expenditure are in line with the results of the research conducted by Marfiana \& Kurniasih (2013). However, for the BPK audit findings and opinion variables do not have an influence on performance. $\mathrm{Ku}$ suma \& Handayani (2017) obtained the results that size and leverage do not affect on performance, while the variables of wealth level and expenditure have the same result. This result is different from the results of the studies conducted by Mustikarini \& Fitriasari (2012) and Harumiati \& Payamta (2014) that is, size has no effect, wealth level has a positive effect and expenditure and BPK audit findings have a significant negative effect on LG performance. Research conducted by Masdiantini \& Erawati (2016) finds size and audit opinion have a significant positive effect, while wealth level and audit findings have no effect as well as Sumarjo (2010) found size and leverage has significant positive effect while the level of wealth has no effect.

The differences in the results of the previous studies allow the researchers to propose a new variable in this study, namely governance complexity as an independent variable. The use of government complexity variable here is expected to see whether government complexity can affect the dependent variable in this study. Throughout the knowledge of researchers, the use of government complexity variable as an independent variable on local government financial performance variable has never been done before. The purpose of this study is to determine the effect of size, regional expenditure, regional wealth level, leverage, government complexity, BPK audit findings and opinions on the financial performance of local governments. The originality in this research is the use of government complexity variable as an independent variable on the variable of the financial performance of local government.

Wahyudin \& Solikhah (2017)such as return on assets, return on equity and earnings per share. However, CG implementation rating is not directly responded by the Indonesian stock market and has not yet been able to increase the company?s growth in the short term. Research limitations/implications In this study, CGPI rating in a related year is linked to market performance in the same year. Thus, further research may link CGPI rating to market performance in the next year, as the findings of this study show that GCG implementation is not directly responded by the market. Practical implications GCG implementation is required by stakeholders, as it may give a long-term positive impact. Thus, the government needs to stipulate regulations to increase the commitment of the company in implementing GCG. The company can improve the internal factors of the organization that does not support the establishment of GCG based on the findings during the survey of CGPI. Finally, investors and creditors may consider the CGPI rating for their investment decisions. Originality/value This study contributes to the literature in two ways. First, this study uses the comprehensive CG rating in Indonesia. Previous studies on CG rating focused on internal mechanism; in this study, the rating was assessed using four stages of continuous assessment: self-assessment, document evaluation, paper assessment and company visit, which was conducted by an independent team. Second, this study uses the CG index (compliance, conformance and performance also explained the concept of agency theory by Jensen and Meckling which explains the relationship between principal and agent, where one party (the principal) delegates his work to other party (the agent). According to Lane (2013) and Moe (1984) agency theory can be applied to public sector organizations. Agency theory is a concept that explains the contractual relationship between principals and agents. Principals are parties that give mandates to other parties, namely agents, to carry out all activities on behalf of the principals in their capacity as decision makers ( Jensen \& Smith, 1984).

One of the government's goals is to improve performance, namely service to the community. To provide optimal services, of course, local governments need financial support, which is enough assets to be able to provide the best performance to the community. Agency theory views the local government as an agent considered to be acting with full awareness for its own interests. Thus, the greater the size of the region marked by the large number of LG assets, the higher the LG performance is expected to be (Mustikarini \& Fitriasari, 2012). Research results of Taylor et al., (2010), Wright et al., (2009), Sumarjo (2010), Mustikarini \& Fitriasari (2012) as well as Masdiantini \& Erawati (2016) which state that the size of the LG has a positive effect on financial performance.

\section{$H_{1}$ : Regional size has a positive effect on the finan- cial performance of local governments}

Local governments that have the autonomy right to manage the budget Local governments must be able to use the resources owned by the region to realize prosperity and meet the expectations and interests of the public or the society. Thus, local governments with a large total expenditure should be able to provide good performance. In agency theory, the community as the principal has the right to give evaluation and evaluation on the performance of the Regional Government in order to good performance of services and welfare for the community can be better. Therefore, the Local Government is certainly required to be able to manage expenditures that can improve performance to the public. Some studies on regional expenditure have been carried out by Sjoberg (2003), Marfiana \& Kurniasih (2013), and Noviyanti \& Kiswanto (2016) which prove that regional expenditure has a positive effect on the financial performance of local government. 
$\mathrm{H}_{2}$ : Regional expenditure has a positive effect on the financial performance of local government

The level of regional wealth is reflected in the increase in Locally-Generated Revenue (PAD) which is all regional revenue that comes from the regional original economic sources. Sumarjo (2010) also explained an increase in PAD is actually an access to economic growth. Positive growth encourages investment, the investment will encourage regional development so that it can better reflect local government services. It can be concluded that the greater the amount of PAD will be able to improve LG performance. Local governments as agents according to agency theory cannot be trusted by principals to act as well as possible for the interests of the community. This relates to the wealth owned by the region which will later be utilized by the Local Government in an effort to realize public expectations for good service and performance. Research conducted by Lin et al., (2011) finds that Local government revenue has a positive effect on the performance of LGs in China. Likewise research conducted by Mustikarini \& Fitriasari (2012) which has a consistent result that the level of wealth is positively correlated to LG performance.

\section{$\mathrm{H}_{3}$ : The level of regional wealth has a positive effect on the financial performance of local govern- ments}

Leverage in this study illustrates the ratio of debt and equity owned by each LG. Leverage shows operational funding sources and investments that come from outside the company (Ingram \& Lee, 1997; Pinnuck \& Potter, 2009; Fanani et al., 2011; Okfitasari, 2015; Riantani \& Nurzamzam, 2015). The higher the LG leverage ratio indicates the lower performance, because it indicates that the LG is unable to finance its own operations. Agency theory by Jensen \& Meckling (1976) explains about monitoring costs, bonding costs, and residual loss. The measurement of debt ratio is important to do. To see the extent to which regional governments are in control of the funds and debts management.

This is confirmed in the studies conducted by Sudarmaji \& Sularto (2007), Weill (2003) and Sumarjo (2010) which find a correlation between leverage and the financial performance of local government.

\section{$\mathrm{H}_{4}$ : Leverage has a negative effect on the financial performance of local governments}

Governance complexity illustrates the conditions in which there are various factors with different characteristics that affect governance both directly and indirectly. The complexity of an area is a level of differentiation that exists in the local government that causes conflict or problems in order to achieving goals (Saputro \& Mahmud, 2015). Agency theory explains that there are two parties who make an agreement. Agency problems arise when the principal delegates decision-making authority to the agent (Schunk \& Zimmerman, 1977). Here, the SKPD becomes one of the agents who receives authority from the principal to carry out their duties in financial management and compile the financial state- ments of local government which will be used by the principal to see how the performance of LG.

Maulana \& Handayani (2015) argued that the more complex the government, it is needed greater disclosure to help readers of financial statements understand the complexity of the activities carried out by the government. The greater the SKPD it has, the more complex the government is, and can encourage a decrease in the level of LG performance, because it is faced with a high risk of various fraud. Where SKPD is the executive function manager who must coordinate so that the management of government runs well. In addition, each employee must also have a strong organizational commitment to provide the best performance for the country and the best service for the community (Putri \& Mahmud, 2015). This is supported by research result of Patrick (2007) which states that functional differentiation influences the application of a new innovation, GASB 34.

\section{$\mathrm{H}_{5}$ : Governance complexity has a negative effect on the financial performance of regional govern- ments}

Agency theory assumes that there is a lot of information asymmetry between agents and principals where agents have direct access to information. It makes the possibility for fraud or corruption by agents. Research conducted by Bernstein (2001) concluded there is a relationship between LG performance measurements and monitoring system, including performance audits and program evaluations. The more fraud committed by the local government or the number of BPK audit findings illustrate the poor performance of the local government. According to agency theory, the local government must be monitored to ensure that management is carried out in accordance with applicable rules and regulations. Research conducted by Harumiati \& Payamta (2014) as well as Marfiana \& Kurniasih (2013) find that the audit finding variable has a negative effect on the financial performance of local government.

\section{$H_{6}$ : BPK audit findings have a negative effect on the financial performance of local government}

Ikhtisar Hasil Pemeriksaan Semester II 2016 explained that the financial audit is carried out in order to provide an opinion on the fairness of the financial information presented in the financial statements. This opinion can increase or decrease the level of stakeholder trust in the reporting presented by the auditee, in this case the LG entity. Agency theory explains that LGs as agents cannot be trusted to act for the public interest. BPK's opinion can be a benchmark (indicator) to assess the accountability of a government entity. In other words, the more reasonable the BPK audit opinion, the higher the performance of a regional government should be. Research conducted by Virgasari (2009), Wendy (2012) and Indrarti (2011) show that there is a relationship between BPK's audit opinion on the financial performance of local government.

\section{$\mathrm{H}_{7}$ : BPK's audit opinion has a positive effect on the financial performance of local government}




\section{RESEARCH METHODS}

This research was a quantitative study with the type of data used was secondary data. The population of this study were 258 populations from 129 regencies / cities in Java Bali Island in the fiscal year 2014-2015. The sampling technique used was purposive sampling which produced 202 final samples.

Table 1. Detail of Sampling

\begin{tabular}{llrr}
\hline \multirow{2}{*}{ No } & \multicolumn{1}{c}{ Criteria } & $\begin{array}{r}\text { Beyond } \\
\text { Criteria }\end{array}$ & $\begin{array}{r}\text { Included } \\
\text { Criteria }\end{array}$ \\
\hline & Total population & & 129 \\
1 & Regency / City Government & $(07)$ & 122 \\
2 & $\begin{array}{l}\text { Having complete data for the } \\
\text { measurement all variables }\end{array}$ & $(02)$ & 120 \\
3 & Outlier data & \\
\hline $\begin{array}{l}\text { Total research data for the } \\
\text { year 2014-2015 }\end{array}$ & & 201 \\
\hline Source: Secondary data processed, 2018
\end{tabular}

The dependent variable in this study was the fi- nancial performance of local government. The independent variables in this study are size, regional expenditure, level of regional wealth, leverage, government complexity, BPK audit findings and opinion. The operational definition of dependent and independent variables can be seen in the Table 2.

BPK RI The data collection technique was carried out with the documentation technique of the Regency / City LHP LKPD located in Java Bali Island in the fiscal year 2014-2015 audited by BPK RI. Sources of Regency / City LHP LKPD data were obtained directly from the BPK RI Information and Communication Center. Meanwhile, data for the audit finding variable was obtained from IHPS I and II in 2015-2016. The analysis technique used was descriptive statistical analysis, classical assumption tests and multiple regression analysis. The mathematical model used in this study is as follows: $\mathrm{Y}=\alpha+\beta 1 \mathrm{SIZE}+\beta 2 \mathrm{BD}+\beta 3 \mathrm{KYD}+\beta 4 \mathrm{LEV}+\beta 5 \mathrm{KP}+$

$\beta 6 \mathrm{TA}+\beta 7 \mathrm{OA}+\mathrm{e} .$.

Table 2. Operational Definition

\begin{tabular}{|c|c|c|}
\hline Variables & Definition & Measurement \\
\hline $\begin{array}{l}\text { Local Government fi- } \\
\text { nancial performance } \\
\text { (Y) }\end{array}$ & $\begin{array}{l}\text { Performance is defined as the mea- } \\
\text { sured activity of an entity during a } \\
\text { certain period as part of a measure of } \\
\text { work success (Ahzar 2008). }\end{array}$ & $\begin{array}{l}\text { Efficiency }=\frac{\text { Expenditure Realization }}{\text { Revenue Realization }} \\
\text { Sumarjo (2010) }\end{array}$ \\
\hline
\end{tabular}

Regional Size (SIZE) Size into a scale that can be classified large or Size $=$ Ln Total Asset small (Suwito \& Herawaty, 2005).

Francis et al. (2004);Plummer et al. (2007); Pinnuck \& Potter (2009)

Regional Expenditure Regional expenditure is all regional obliga- Regional Expenditure $=$ Ln Total Realiza(BD) tions that are recognized as a deduction of tion of Regional Expenditures net wealth value in the relevant fiscal year Bingham (1978); Lin \& K. K. (1998); Kuperiod (UU 32, 2004). suma \& Handayani (2017)

Level of regional The level of regional wealth is reflected by wealth (TKD) the amount of PAD (Sumarjo, 2010).

Wealth $=\frac{\text { Total } P A D}{\text { Total Revenue }}$

Kusumawardani (2012)

Government Com- The complexity of an area is a level of dif-

plexity (KP) ferentiation that exists in Local Government SKPD = Total SKPD (Saputro \& Mahmud, 2015). Differential Hilmi et al., (2012); Suhardjanto \& functions are coalitions of implementing Yulianingtyas (2011) units in the administration system (Damanpour, 1991).

Leverage (LEV) Leverage is the level of use of debt as a Leverage is the level of use of debt as a
source of corporate finance (Widiatmoko \& DER $=\frac{\text { Total Liabilities }}{\text { Total Equities }}$
Mayangsari, 2016).

Okfitasari (2015)

BPK audit findings BPK audit findings are in the form of BPK's Findings $=$ Total findings audit results on the local government finan- Marfiana \& Kurniasih (2013) cial statements that reveal the existence of weaknesses in the internal control system and violations of non-compliance with statutory provisions Marfiana \& Kurniasih (2013).

BPK audit opinion Opinion is a professional statement as the au- 5 point scale

(OA) ditor's conclusions about the level of reason- Asmoko (2012); Masdiantini \& Erawaableness of the information presented in the ti (2016) financial statements (Setiawan, 2012). 


\section{RESULTS AND DISCUSSIONS}

Descriptive statistical analysis describes the minimum, maximum, mean and standard deviation values for each variable in this study showing local government financial performance, size, regional expenditure, regional wealth level, government complexity and BPK audit opinion having mean values greater than standard deviation $(\mathrm{Y}=0.9656>0.0481$; SIZE $=28.7748>0.67130$; $\mathrm{BD}=28.1151>0.46608 ; \quad \mathrm{KYD}=0.1857>0.12941$; $\mathrm{KP}=58.6931>25.96160 ; \quad \mathrm{OA}=4.0545>0.98345)$. This means that the data distribution for each variable is good. Whereas for leverage and BPK audit findings have mean lower than the standard deviation (LEV $=0.0364$ $<0.24771$; $\mathrm{TA}=6.0891<8.227464)$ meaning that the data distribution is not good.

The classical assumption test includes the normality test with Kolmogorov-Smirnov test showing the value of Asymp. Sig (2-tailed) $0.786>0.05$, the multicollinearity test with tolerance value $>0.1(\mathrm{SIZE}=0.304$; $\mathrm{BD}=0.366 ; \mathrm{KYD}=0.658 ; \mathrm{LEV}=0.928 ; \mathrm{KP}=0.931 ;$ $\mathrm{TA}=0.899 ; \mathrm{OA}=0.830 ; 0.912)$ and $\mathrm{VIF}<10(\mathrm{SIZE}=$ 3.286; $\mathrm{BD}=2.731 ; \mathrm{KYD}=1.520 ; \mathrm{LEV}=1.078 ; \mathrm{KP}$ $=1.074 ; \mathrm{TA}=1.112 ; \mathrm{OA}=1.096)$, heteroscedasticity test with Glejser test shows that all variables has Sig.> 0.05 (SIZE $=0.829 ; \mathrm{BD}=0.829 ; \mathrm{KYD}=0.134 ; \mathrm{LEV}=$ $0.637 ; \mathrm{KP}=0.097 ; \mathrm{TA}=0.155 ; \mathrm{OA}=0.260$ ) and autocorrelation test with Runs Test shows the value of Asymp. Sig (2-tailed) $1.000>0.05$ and it is concluded that the data in this study are free from deviations in other words the classical assumption tests have been fulfilled.

The coefficient of determination or adjusted $\mathrm{R}^{2}$ shows the results of 0.238 which shows that the research model is able to explain $23.8 \%$ of the variation of the capital structure, while $76.2 \%$ is explained by other variables. The results of hypothesis testing with a significance level $(\square=5 \%)$ are presented in Table 3. Mathematical model of statistical test results:

$$
\begin{aligned}
& \mathrm{Y}=0,207+-0,044 \mathrm{SIZE}+0,070 \mathrm{BD}+-0,020 \mathrm{KYD}+ \\
& \text { 0,000LEV + -9,780E-006 KP + 6,415E-005TA + } \\
& 0,012 \mathrm{OA} \text {. }
\end{aligned}
$$

\section{The Effect of Regional Size on the Financial Perfor- mance of Local Government}

The result of hypothesis test shows that regional size has a negative effect on the financial performance of local performance. Thus, it can be concluded that $\mathrm{H}_{1}$ is rejected, which means that regional does not have a positive effect but has a negative effect on the financial performance of Local Government, because the result of the t-count is negative. This negative relationship can be explained where the LGs that have a large amount of assets will also be followed by a large risk of abuse / corruption, so that it can reduce the financial performance of the Local Government. Supported by agency theory, where there are agency problems that might arise due to the delegation of authority. This was also stated by Durnev \& Kim (2003) that large companies tend to become public concern. The result of this study is in line with the result of the study conducted by Mulyani \& Wibowo (2017) which states that there is a significant negative effect between the size of the region and the financial performance of the Local Government.

\section{The Effect of Regional Expenditures on the Financial Performance of Local Government}

The result of hypothesis test shows that regional expenditure has an effect on the financial performance of the Local Government. Thus, it can be concluded that $\mathrm{H}_{2}$ is accepted, which means that regional expenditure has a positive effect on the LG's financial performance. The amount of expenditure spent by a region can ease the Local Government to carry out the development program that has been designed. That way, LGs with

\begin{tabular}{|c|c|c|c|c|c|}
\hline & Hypothesis & $\begin{array}{c}\text { Unstan- } \\
\text { dardized } \\
\text { Coefficient } \\
\beta\end{array}$ & $\begin{array}{l}\text { Count } \\
\text { Value }\end{array}$ & Sig. & Results \\
\hline $\mathrm{H}_{1}$ & $\begin{array}{l}\text { Regional size has a positive effect on the financial perfor- } \\
\text { mance of local governments. }\end{array}$ & -0.044 & -5.490 & 0.000 & Rejected \\
\hline $\mathrm{H}_{2}$ & $\begin{array}{l}\text { Regional expenditure has a positive effect on the financial } \\
\text { performance of local government. }\end{array}$ & 0.070 & 6.673 & 0.000 & Accepted \\
\hline $\mathrm{H}_{3}$ & $\begin{array}{l}\text { The level of regional wealth has a positive effect on the fi- } \\
\text { nancial performance of local government. }\end{array}$ & 0.020 & 0.693 & 0.489 & Rejected \\
\hline $\mathrm{H}_{4}$ & $\begin{array}{l}\text { Leverage has a negative effect on the financial performance } \\
\text { of local government. }\end{array}$ & 0.000 & 0.024 & 0.981 & Rejected \\
\hline $\mathrm{H}_{5}$ & $\begin{array}{l}\text { Governance complexity has a negative effect on the finan- } \\
\text { cial performance of regional governments. }\end{array}$ & $-9.780 \mathrm{E}-006$ & -0.083 & 0.934 & Rejected \\
\hline $\mathrm{H}_{6}$ & $\begin{array}{l}\text { BPK audit findings have a negative effect on the financial } \\
\text { performance of local government. }\end{array}$ & $-6.415 \mathrm{E}-005$ & 0.170 & 0.865 & Rejected \\
\hline $\mathrm{H}_{7}$ & $\begin{array}{l}\text { BPK's audit opinion has a positive effect on the financial } \\
\text { performance of local government. }\end{array}$ & 0.012 & 3.793 & 0.000 & Accepted \\
\hline
\end{tabular}
large total expenditures can provide good performance.

Table 3. Summary of Hypothesis Testing

Source : Data processed, 2018 
This is supported by agency theory, where the community as the principal has the right to provide an evaluation and can provide an assessment that the LG's performance is good. This result is strengthened by the results of the studies conducted by Marfiana \& Kurniasih (2013), Noviyanti \& Kiswanto (2016) as well as Sjoberg (2003) which state that there is a positive relationship between government expenditure and macroeconomic performance in Sweden during the 1960s to 2001.

\section{The Effect of Regional Wealth Level on the Financial Performance of the Local Government}

The result of hypothesis test indicates the level of regional wealth does not affect on the financial performance of the local government. Thus, it can be concluded that $\mathrm{H}_{3}$ is rejected which means that the level of regional wealth does not have a positive effect on the financial performance of the Local Government. The Local government as the agents according to agency theory cannot be trusted by the principal to act as well as possible for the interests of the community. This can be explained because the Local Government used as the sample in this study has a relatively small PAD value so that it makes the level of regional wealth cannot significantly influence the financial performance of the Local Government. The result of this study is not in line with the studies conducted by Harumiati \& Payamta (2014) and Mustikarini \& Fitriasari (2012). The result of this study is in line with the studies conducted by Noviyanti \& Kiswanto (2016), Marfiana \& Kurniasih (2013) and Coll et al., (2007).

\section{The Effect of Leverage on the Financial Performance of the Local Government}

The result of hypothesis test indicates leverage does not affect on the financial performance of the Local Government. Thus, it can be concluded that $\mathrm{H}_{4}$ is rejected which means that leverage does not has negative effect on the financial performance of the local government. This is explained that the reason leverage has no effect is because the ratio of debt held by the Local Government is far too small when compared to the equity of funds owned. Agency theory by Jensen \& Meckling (1976) explained monitoring costs, bonding costs and residual loss. However, if leverage is applied in the local government, the leverage position cannot be compared to the condition of a business unit because the external financing of the local government does not only come from debt but also comes from central government assistance funds, namely the Balancing Fund (Noviyanti \& Kiswanto, 2016). The result of this study does not support the study conducted by Sumarjo (2010) which find the result that leverage has a negative effect on the financial performance of local government. The result of this study is in line with studies conducted by Kusuma \& Handayani (2017), Kusumawardani (2012), which state that leverage has no effect on the financial performance of local government.

\section{The Effect of Governance Complexity on the Finan- cial Performance of the Local Government}

The result of hypothesis test indicates government complexity does not affect on the financial performance of the local government. Thus, it can be concluded that $\mathrm{H}_{5}$ is rejected which means that government complexity does not have a negative effect on the financial performance of the Local Government. Based on the hypothesis result of the sixth hypothesis, it can be seen that there is a negative direction from the result of the test between government complexity towards the financial performance of the Local Government, which shows that the more complex affairs of a government can encourage the possibility of decreasing the performance of the Local Government. Because the Local Government that has a high level of complexity are also faced with a great challenge to fraud that can occur which affects the decline in financial performance. The statement is also supported by the study of Doyle et al., (2007). Agency theory explains that there are two parties who make an agreement. Agency problems arise when the principal delegates decision-making authority to the agent (Schunk \& Zimmerman, 1977). This is supported by the research result of Patrick (2007) which proves that functional defferentiation influences the application of a new innovation, GASB 34.

\section{The Effect of BPK Audit Findings on the Financial Performance of Local Government}

The result of hypothesis test indicates BPK audit findings do not affect on the financial performance of Local Government. Thus, it can be concluded that $\mathrm{H}_{6}$ is rejected, which means that BPK's audit findings have no effect on the financial performance of Local Government. Noviyanti \& Kiswanto (2016) Hal stated that Local Government which obtain a large number of audit findings do not necessarily have poor LG financial performance. This can be explained because the number of findings that are proxied by the number of cases is less able to describe the financial performance because of the findings of the problem by BPK not only are reported to have a financial impact, but there are also findings in the form of administrative problems that do not have a financial impact so that the number of findings alone cannot have a significant effect. This is supported by agency theory in which the Local Government must be monitored to ensure that management is carried out in accordance with applicable rules and regulations, so that it can guarantee the accountability expected by the community. The result of this study is in line with research conducted by Masdiantini \& Erawati (2016) and Noviyanti \& Kiswanto (2016).

\section{The Effect of BPK Audit Opinions on the Financial Performance of Local Government}

The result of hypothesis test shows that BPK's audit opinion has an effect on the financial performance of local government. Thus, it can be concluded that $\mathrm{H}_{7}$ is accepted which means that BPK's audit opinion has 
Yulia Wijayanti \& Dhini Suryandari, The Effect of Regional Characteristics, Leverage, Government Complexity, BPK Audit ...

a positive effect on the financial performance of local government. Research conducted by Virgasari (2009) shows that there is a fairly strong positive relationship between BPK audit opinion on the financial performance of the local government in terms of the concept of value for money. Agency theory explains that the local governments as agents cannot be trusted to act in the public interest. The BPK audit opinion is the auditor's professional statement regarding the reasonableness of the financial information presented in the financial statements. The better the BPK audit opinion is obtained, it can show the improved performance of the Local Government on regional financial management. The result of this study is in line with studies conducted by Masdiantini \& Erawati (2016), Meiden (2008), Virgasari (2009) which state that audit opinion influences the local government's financial performance.

\section{CONCLUSIONS}

Based on the data analysis and discussion, it can be concluded that simultaneous testing shows the effect between independent and dependent variables. Size, regional expenditure, and BPK audit opinion have a significant effect on the financial performance of the local Government and the level of regional wealth, leverage, government complexity, and BPK audit findings have no significant effect on the financial performance of the Local Government. The limitations of the study are (1) This study uses LHP LKPD data 2014-2015. The use of more time can give more description of the practice of local government financial performance on the island of Java, Bali; (2) Limited variables used. Based on the research results and conclusions above, the suggestion that can be given for further research is that it is recommended to use other proxies for audit findings, for example the value of findings in rupiah. This is due to the value of the findings in rupiah will be more financially visible and will be precisely related to financial performance.

\section{REFERENCES}

Asmoko, H. (2012). Korelasi Opini Audit BPK atas LKKL dengan Hasil Evaluasi LAKIP K/L. Badan Pendidikan Dan Pelatihan Keuangan KEmentrian Keuangan, 1-13.

Azhar, M. K. S. (2008). Analisis Kinerja Keuangan Pemerintah Daerah Kabupaten/Kota Sebelum Dan Setelah Otonomi Daerah. Tesis. Universitas Sumatera Utara.

Balaguer-Coll, M. T., Prior, D., \& Tortosa-Ausina, E. (2007). On the determinants of local government performance: A two-stage nonparametric approach. European Economic Review, 51(2), 425-451.

Bernstein, D. J. (2001). Local government measurement use to focus on performance and results. Evaluation and Program Planning, 24, 95-101.

Bingham, D. R. (1978). Innovation, Bureaucracy and Public Policy: A Study of Innovation Adoption by Local Goverment. The Western Political Quarterly, 31(2), 178205.

Chow, C., Ganulin, D., Teknika, O., Haddad, K., \& Williamson, J. (1998). The Balanced Scorecard: A Potent Tool for Energizing and Focusing Healthcare Organization Management. Journal of Healthcare Management / American College of Healthcare Executives, 43(3), 263-280.
Damanpour, F. (1991). Organizational Innovation: A MetaAnalysis of Effects of Determinants and Moderators. The Academy of Management Journal, 34(3), 555-590.

Doyle, J. T., Ge, W., \& McVay, S. E. (2007). Determinants of Weaknesses in Internal Control over Financial Reporting. Journal of Accounting and Economics, 44(1-2),193223.

Durnev, A., \& Kim, E. H. (2003). To Steal or Not to Steal : Firm Attributes, Legal Environment, and Valuation (No. 554) (Vol. LX).Working Paper.

Fanani, Z., Ningsih, S., \& Hamida. (2011). Faktor-Faktor Penentu Kualitas Pelaporan Keuangan dan Kepercayaan Investor. In Simposium Nasional Akuntansi XII (1-32).

Francis, J., Lafond, R., Olsson, P. M., Schipper, K., Francis, J., Lafond, R., \& Schipper, K. (2004). Costs of Equity and Attributes. The Accounting Review, 79(4), 967-1010.

Harumiati, Y., \& Payamta. (2014). Pengaruh Karakteristik Pemerintah Daerah dan Temuan Audit BPK terhadap Kinerja Pemerintah Daerah Kabupaten/Kota Di Indonesia Tahun Anggaran 2011. Jurnal Akuntansi Dan Pendidikan, 3(2), 75-87.

Hilmi, Z., Amiruddin, \& Martani, D. (2012). Analisis FaktorFaktor yang Memperngaruhi Tingkat Pengungkapan Laporan Keuangan Pemerintah Provinsi. In Simposium Nasional Akuntansi XV.

Ikhtisar Hasil Pemeriksaan Semester II. Retrieved from http:// www.bpk.go.id/assets/files/ihps/2016/II/ihps_ ii_2016_1491461165.pdf

Indrarti, N. M. O. (2011). Hubungan antara Opini Audit pada Laporan Keuangan Daerah, Pendapatan Asli Daerah (PAD) dan Dana Alokasi Umum (DAU) terhadap Kinerja Keuangan Daerah. Jurnal Akuntansi Dan Keuangan Indonesia, 9(2), 154-170.

Ingram, R. W., \& Lee, T. A. (1997). Information provided by accrual and cash-flow measures of operating activities. Abacus, 33(2), 168-185.

Jensen, M. C., \& Meckling, W. H. (1976). Theory of the Firm : Managerial Behavior, Agency Costs and Ownership Structure Theory of the Firm : Managerial Behavior, Agency Costs and Ownership Structure. Journal of Financial Economics, 3(4), 305-360.

Jensen, M. C., W., C., Smith, \& Jr. (1984). The Theory of Corporate Finance : A Historical Overview. In The Modern Theory of Corporate Finance (Vol. , pp. 2-20). New York: McGraw-Hill Inc.

Kurrohman, T. (2013). Evaluasi Penganggaran berbasis Kinerja melalui Kinerja Keuangan yang berbasis Value for Money di Kabupaten/Kota di Jawa Timur. Jurnal Dinamika Akuntansi, 5(1), 1-11.

Kusuma, A. R., \& Handayani, N. (2017). Pengaruh Karakteristik Pemerintah Daerah terhadap Efisiensi Kinerja Keuangan Pemerintah Daerah. Jurnal Ilmu Dan Riset Akuntansi, 6(1), 403-420.

Kusumawardani, M. (2012). Pengaruh Size, Kemakmuran, Ukuran Legislatif, Leverage terhadap Kinerja Keuangan Pemerintah Daerah di Indonesia. Accounting Analysis Journal, 1(1), 27-35.

Lane, J.-E. (2013). The Principal-Agent Approach to Politics: Policy Implementation and Public Policy-Making *. Journal of Political Science, 3(2), 85-89.

Lin, M. I., Lee, Y. D., \& Ho, T. N. (2011). Applying integrated DEA/AHP to evaluate the economic performance of local governments in China. European Journal of Operational Research, 209(2), 129-140.

Lin, W., \& K. K., R. B. (1998). The Housing Value-Relevance of Govermental Accounting Information. Journal of 
Accounting and Public Policy, 1(7).

Marfiana, N., \& Kurniasih, L. (2013). Pengaruh Karakteristik Pemerintah Daerah dan Hasil Pemeriksaan Audit BPK terhadap Kinerja Keuangan Pemerintah Daerah Kabupaten/Kota. E-Jurnal Ekonomi Universitas Sebelas Maret, 1(1).

Masdiantini,P.R.,\&Erawati,N.M.A.(2016).PengaruhUkuran Pemerintah Daerah, Kemakmuran,Intergovernmental Revenue, Temuan dan Opini Audit BPK pada Kinerja Keuangan. E-Jurnal Akuntansi Universitas Udayana, 14(2), 1150-1182.

Maulana, C., \& Handayani, B. D. (2015). Pengaruh Karakteristik, Kompleksitas Pemerintahan dan Temuan Audit terhadap Tingkat Pengungkapan Wajib LKPD. Accounting Analysis Journal, 4(4), 1-11.

Meiden, C. (2008). Pengaruh opini audit terhadap return dan volume perdagangan saham. Akuntabilitas, 7(2), 109113.

Moe, T. M. (1984). The New Economic of Organization. American Journal of Political Science, 28(5), 739-777.

Mulyani, S., \& Wibowo, H. (2017). Pengaruh Belanja Modal, Ukuran Pemerintah Daerah, Intergovernmentalrevenue Dan Pendapatan Asli Daerah terhadap Kinerja Keuangan. Jurnal Kompartemen, XV(1), 57-66.

Mustikarini, W. A., \& Fitriasari, D. (2012). Pengaruh Karakteristik Pemerintah Daerah dan Temuan Audit BPK terhadap Kinerja Pemerintah Daerah Kabupaten/ Kota di Indonesia Tahun Anggaran 2007. In Simposium Nasional Akuntansi XV (1-22). Banjarmasin: 20-23 September.

Noviyanti, N. A., \& Kiswanto. (2016). Pengaruh Karakteristik Pemerintah Daerah, Temuan Audit BPK terhadap Kinerja Keuangan Pemerintah Daerah. Accounting Analysis Journal, 5(1), 1-10.

Okfitasari, A. (2015). Karakteristik Pemerintah Daerah dan Kualitas Pelaporan Keuangan Pemerintah Daerah(Studi Empiris: Pemerintah Daerah Se-Jawa Tengah). Jurnal Saitech Politeknik Indonusa Surakarta, 2(4), 10-25.

Patrick, P. A. (2007). The Determinant of Organizational Inovativeness: The Adoption of GASB 34 in Pennsylvania Local Goverment. Dissertation. The Pennsylvania State University.

Pinnuck, M., \& Potter, B. N. (2009). The quality and conservatism of the accounting earnings of local governments. Journal of Accounting and Public Policy, 28(6), 525-540.

Plummer, E., Hutchison, P. D., \& Patton, T. K. (2007). GASB No. 34's governmmental financial reporting model: Evidence on tts information relevance. The Accounting Review, 82(1), 205-240.

Putri, N. K., \& Mahmud, A. (2015). Pengaruh Pertumbuhan Ekonomi, PAD, Ukuran dan Kompleksitas terhadap Kelemahan Pengendalian Intern Pemda. Accounting Analys Journal, 4(2), 1-8.

Riantani, S., \& Nurzamzam, H. (2015). Analysis of Company Size, Financial Leverage, and Profitability and Its Effect to CSR Disclosure. Jurnal Dinamika Manajemen, 6(2), 203-213.

Saputro, E. A., \& Mahmud, A. (2015). Analisis Faktor-Faktor yang Berpengaruh terhadap Kelemahan Pengendalian Intern Pemerintah Daerah. Accounting Analysis Journal, 4(3), 1-9.
Schunk, D. H., \& Zimmerman, B. J. (1977). Social origins of self regulated competence Educational Psychologist, 32(4), 195-208.

Setiawan, W. (2012). Pengaruh Akuntabilitas Laporan Keuangan Pemerintah Daerah (LKPD) Pemerintah Daerah Di Indonesia. Skripsi. Universitas Diponegoro.

Sjoberg, P. (2003). Government Expenditures Effect on Economic Growth The Case of Sweden 1960-2001. Thesis. Lulea University of Technology.

Sudarmadji, A. M., \& Sularto, L. (2007). Pengaruh Ukuran Perusahaan, Profitabilitas, Leverage, dan Tipe Kepemilikan Perusahaan terhadap Luas Voluntary Disclosure Laporan Keuangan Tahunan. In Proceeding PESAT Vol. 2, pp. 53-61). Depok: Gunadarma University.

Suhardjanto, D., \& Yulianingtyas, R. R. (2011). Pengaruh Karakteristik Pemerintah Daerah terhadap Kepatuhan Pengungkapan Wajib dalam Laporan Keuangan Pemerintah Daerah. Jurnal Akuntansi \& Auditing, 8(1), 30-42.

Sumarjo, H. (2010). Pengaruh Karakteristik Pemerintah Daerah terhadap Kinerja Keuangan Pemerintah Daerah. Skripsi. Universitas Negeri Sebelas Maret.

Suwito, E., \& Herawaty, A. (2005). Analisis Pengaruh Kharakteristik Perusahaan terhadap Tindakan Perataan Laba yang Dilakukan oleh Perusahaan yang Terdaftar di Bursa Efek Jakarta. In Simposium Nasional Akuntansi VIII. Solo.

Taylor, P., Lin, F., Chang, C., \& Wu, S. (2010). A Study on The Relationship Between Related Party Transactions and Monthly Sales in Taiwan's Publicly Issued Companies. Journal of the Chinese Institute of Industrial Engineers, 26(5), 337-343.

Virgasari, A. (2009). Hubungan Antara Opini Auditor pada Laporan Keuangan Daerah, Pendapatan Asli Daerah(PAD) dan Dana Alokasi Umum(DAU) dengan Kinerja Keuangan Daerah. Skripsi. Universitas Brawijaya.

Wahyudin, A., \& Solikhah, B. (2017). Corporate governance implementation rating in Indonesia and its effects on financial performance. The International Journal of Business in Society, 17(2), 260-265.

Weill, L. (2003). Leverage and Corporate Performance: A Frontier Efficiency Analysis on European Countries. Working Paper. SSRN.

Wendy, B. (2012). Pengaruh Opini, Temuan Audit dan Gender terhadap Kinerja Penyelenggaraan Pemerintah Daerah Kabupaten/Kota di Indonesia Tahun 2008-2010. Skripsi. Universitas Indonesia.

Widiatmoko, J., \& Mayangsari, I. (2016). The Impact of Deferred Tax Assets, Discretionary Accrual, Leverage, Company Size and Tax Planning Onearnings Management Practices. Jurnal Dinamika Manajemen, 7(1), $22-31$.

Wood, L. (1998). Local Goverment Dollars \& Sense. In Training Shoppe (Ed.), Rancho Palos Verdes (p. ). CA.

Wright, P., Kroll, M., Mukhreji, A., \& Pettus, M. L. (2009). Do the Conti-ngencies of External Monitoring, Ownership Incentives, or Free Cash Flow Explain Opposing Firm Performance Expectations? Journal Management Governance, 13, 215-243. 